\title{
EDUCATION FOR LIBRARIANSHIP: A SURVEY OF THE LITERATURE, 1988-1995
}

\author{
by Rashelle S. Karp \\ assisted by Tonya Allon
}

\section{Introduction}

Clarion University of Pennsylvania's Department of Library Science (DLS) has been offering an accredited Master of Science in Library Science degree since 1976; the program has been reaccredited twice since its original accreditation, and recently completed the process of self study associated with an accreditation visit in the spring of 1996. This was an exciting time for the Faculty of the DLS, especially since it was the first time that the Faculty used the new Standards for Accreditation of Master's Programs in Library and Information Studies (Office, 1992). One of the hallmarks of the new accreditation standards is theiremphasis on "broad- based, continuous program planning, development and improvement," (Office, 1992, p. 3) and their emphasis on "systematic planning process[es]" (Office, 1992, p. 11. Additionally, the new standards emphasize the need to develop a curriculum which "reflects the findings of basic and applied research from relevant fields," and which takes into account "the statements of knowledge and competencies developed by relevant professional organizations" (Office, 1992, pp. 11-12). Since 1983, the DLS Faculty have utilized a fiveyear process of continuous curriculum revision which begins with a comprehensive search of the literature about education for librarianship and competencies needed by librarians. Following is a summary of the competencies and suggested curriculum components which were indicated in the literature about librarianship, 1988-1994.

\section{Library Science Graduate Programs}

Literature about graduate education in library science points to a definition of the process as a "pluralistic," - i.e., interdisciplinary and diverse - mix of multiple raditions, standards, methods, and userneeds (Robbins, 1990; Lowry, 1990; Tees, 1991; Bradley, 1993; Koenig, 1993; Ostler, 1995) within which there exist theory (Boyce, 1994) and skills which should be mastered by all MLS graduates, and whose content should be placed within intemational (Fang and Nauta, 1991; Tallman, 1991; Kibirige, 1993) social, economic, cultural, and political contexts (Association of College and Research Libraries, 1992; Sineath, 1992). It is stressed that this process of integration will help to assure that library professionals have a common focus (Oen and Cooper, 1988), pride in their accomplishments (Martin, 1995), and a leadership, self-confident mentality (Penniman, 1991; White, 1995). In addition, the knowledge gained in library school should be applicable at an entry level to a variety of library environments (Preschel, 1988; “Dean's...," 1994). Some writers debate the need for certification of librarians (Ford, 1989; Lindberg, 1990; Kaatrude, 1992; Martin, 1994); others stress the need to provide library school students with field experiences, or internships which provide on-the-job training (Meiseles and Feller, 1994) and which also can be used as recruitment vehicles for minority students (Diaz and Starkus, 1994; Kendrick, Lipkind, and Clinkscales, 1990). Curricula must keep up with new technology (Kaula, 1988; Hurd, 1988; Main, 1990; Sharma, 1992; George, 1994) and that they should include the following components: discussion of ethics (Rogers, 1994) and issues such as equal access to information (McCook, 1992b); balance of theory and practice (Clack, 1993; Curras, 1993); systematic study which integrates basic knowledge and skills into a unified structure (Eisenberg, 1991; Intner, 1991); study of communication theory (Lester, 1993); recognition of the impact of information on individuals and institutions (Anderson, Belkin, Lederman, and Saracevic, 1988); and a holistic approach to integrating knowledge and analysis with professional values (Mayfield, 1993).

It is further stressed that education for librarianship should recognize diverse leaming styles and cultural behaviors among students and library patrons (Alire, 1988; Lenox, 1993a; Lenox, 1993b; Brennan and Sullivan, 1989; Varlejs, 1993/94; Chu, 1994; Hannigan, 1995), especially in terms of information technology education (Johnson, 1991); and that library schools should develop recruitment programs aimed at increasing diversity among library school students and faculty (Miller, 1991; Speller, 
1991; Foderingham-Brown, 1993; McCook, 1993; "Deans...," 1994). Library schools are also urged to recruit and mentor minority students (Abdullahi, 1991) while still maintaining a local perspective on what constitutes a minority hire (Anderson, 1994). Finally, the need for library education to continue beyond the MLS is also emphasized (Nicholson and Bridgeland, 1991; Berry, 1993; Schneider, 1994; Weingand, 1994), especially regarding standards for continued competence and excellence (Weingand, 1991), as well as ability to change (Makinen, 1991). Regarding preparation for library school, practitioners agree that a basic grounding in a variety of disciplinary areas is an advantage (Hayes, 1988). Related to preparation is the issue of how potential students choose a library school; recent research indicates that, in order of importance, students choose library science graduate programs on the basis of their accreditation, cost, options and facilities, technology, specializations, and faculty (Berry, 1994).

Appropriate venues for graduate library science education is a topic which is also discussed in the literature, most often in terms of the best way to provide distance education. Examples of distance education can be found in the literature; many describe the use of interactive television (i.e., "Graduates eam MLS," 1994). Some articles discuss the advantages of distance education such as increased enrollment for the library school (Roper, 1991) and increased student autonomy (Holmberg, 1991); other articles list disadvantages, especially in terms of concerns about quality control for courses taught off-campus (Miller, 1991) and evaluation of students at off-campus locations (Louw, 1994).

\section{Core Curricula}

The literature regarding core curricula categorizes core knowledge and skills into several broad areas:

1. Management, or the ability develop, maintain, and market a library or a specific library service which meets current needs and is able to anticipate and respond to future needs. Within the area of management, library professionals specifically suggest that MLS graduates must be able to market library and information services (Lester, 1993), employ effective time management strategies (Heyser and Heyser, 1989), apply appropriate finance and budgeting skills (Tchobanoff and Price, 1993), think conceptually (Evans and Tipton, 1992), work in groups (Lester, 1993), and evaluate and apply research to decision-making tasks (Connell, 1992).

2. Communication and interpersonal skills, or the ability to transmit information and services which are appropriate and appropriately formatted for a specific audience, and which reflect professionalism and competence. Specific competencies often cited in the areas of communication and interpersonal skills include writing skills (Jul, 1990; Massey-Bursio, 1991); public relations skills (Fisher and Matarazzo, 1993); ability to clearly articulate ideals, principles, concepts and policies (Grey, 1991); ability to understand and communicate with diverse populations (Freiband, 1992); and ability to apply critical thinking skills (Miller, 1990) and personal transferable skills which are not specific to any one subject or discipline (Gash and Reardon, 1988; Dumont, 1989). Venues for teaching these skills via video are well covered in bibliographic resources (Arthur, 1992).

3. Information theory and practice, or the ability to select, acquire, organize, and use information resources in all present formats, and the ability to quickly learn to select, acquire, organize, and use information resources which appear in new formats. In the area of information theory and practice, some library professionals argue that theory should be emphasized in graduate school since practice varies according to institution and information resources used (Carpenter, 1991; Avram, 1991). Among the many specific competencies discussed are ability to acquire, evaluate, organize, and use information and information resources (Fisher and Matarazzo, 1993), including online systems and resources (Settel and Marchand, 1988; Preschel, 1988; Stam, 1992); computer literacy, including knowledge of information systems and their effective management (Tassia, 1990); understanding of a library's environment and its role within that environment (Association of College and Research Libraries, 1992); knowledge of information handling technologies, methods, and techniques, including research techniques (Garrison, 1988); and an understanding of information science as a distinct discipline (Moll and Flood, 1988). Most recently, literature has begun to focus on a new definition of information as a monetary commodity (Cory, 1994).

4. Foundational concepts and skills, or the ability to apply a clear understanding of the profession and its "body of knowledge" to the practice of the profession, both now and in the future. A foundational body of knowledge and skills which all MLS graduates should understand is often couched, in the professional literature, in terms of basic areas of competency, whose theory and practice all MLS graduates should master. These include transferable skills (Lester, 1990); reference theory and practice (Heyser and Heyser, 1989); cataloging and bibliographic control theory and practice (Gorman, 1992); acquisitions and collection development theory and practice (Otero-Boisvert, 1993; Budd and Bril, 1994); circulation theory and practice (DeLuise, 1994); and conservation and preservation theory and practice (DeLuise, 1994). Additionally, an understanding of the basics of facilities planning (DeLuise, 1994), and knowledge of computer applications, technology, and information science (Pemberton, 1990; Stam, 1993) are stressed as important.

\section{"Elective" Curricula for Specialist Education}

The professional literature seems to be quite clear on the issue of specialist education. The preponderance of articles dealing with unique competency requirements for specific types of librarians indicates that a "core" education is not enough to 
adequately prepare an MLS graduate. In addition to the acquisition of core competencies, the library literature identifies several specialist areas within the profession which require "elective" competencies, or competencies which an MLS student "elects" to master, based on her/his individual employment goals.

\section{School Library Media Specialists/Librarians Serving the} Needs of Children. In addition to the core competencies outlined above, school librarians should possess some form of certification (Perritt, 1994). It is also emphasized that school library media specialists must have an understanding of the behavior and psychology of children and young adults (C. Evans, 1993); the development of language and reading skills in children and young adults (Greene and Cullinan, 1988); curriculum design, teaching strategies, cognitive development, and educational theory (Tassia, 1990); and instructional analysis and testing methodologies (Evans and Tipton, 1992). A unique sensitivity to the needs of children and young adults is also heralded (Behrmann and Vogliano, 1991), as is an awareness of the changing dynamics of family life and the impact of family on children and young adults (Lewis, 1993). Additionally, that school librarians must be familiar with and able to use video and digital materials (Evans and Tipton, 1992); must understand the impact of media on children (Fasick, 1990); must be able to plan educational programs for all types of children, including disabled children and children from ethnic and minority groups (Coffeen, 1989); should be able to provide parent education (Greene and Cullinan, 1988); and must have an attitude toward their responsibilities that empowers children to learn (Behrmann, 1991). Library science faculty are urged to instill in students a commitment to continuing professional education (Adams, 1994), and a belief in the centrality of the media center to a school (Eisenberg, 1991). Faculty are also urged to teach students how to persuasively demonstrate the effectiveness and impact of a school library media program and to support professional associations at local, state and national levels (Barron, 1993a; Barron, 1993b). Field experience is strongly recommended (Tassia, 1990), and if this is not possible, simulated teaching exercises via interactive video are suggested as alternatives (Abed, 1988). Regardless of field experiences, school librarians are expected to complete supervised internships (Hempstead, 1988). For public librarians serving the needs of children, necessary competencies include knowledge of children's reading interests and abilities, knowledge of children's literature and children's information needs, programming skills, and advocacy skills (Immroth, 1991; Elkin, 1992).

Public Librarians. The Public Library Association's "Entry Level Public Librarian Competency Statement" states that public librarians must have, in addition to the core competencies outlined previously, knowledge of: 1) the legal, structural, organizational, and regulatory environment of public libraries; 2) the unique nature of a public library's mission and role; 3 ) the role of services and programming in a public library; 4) community structures and public policy mechanisms; and 5) the governance structures within a public library. Additionally, it is stressed that public librarians must possess a well developed code of professional ethics. As was the case with school librarian competencies, field experience in the form of a structured practicum is highly recommended (Lester, 1994). And, the ability to provide programming and services for adult learners is also suggested as important (Duval and Main, 1993).

Reference/Research Librarians. Reference and research librarians are particularly urged to: be able to use research and evaluation methods (Shonrock and Mulder, 1993); understand the research process (Jones, 1991); possess broad and rigorous undergraduate training (McCook and Gonsalves, 1993); be able to provide effective bibliographic instruction which is based on knowledge of many subject areas and teaching strategies, as well as on an understanding of scholarly communication patterns (Mandernack, 1990; Petrowski and Wilson, 1991; White, 1991); be able to conduct effective reference interviews (McMurry, 1988) and develop effective reference search strategies (Collins, 1990); and possess the ability to deal with disruptive elements in the library (Cole, 1993). Library school faculty are especially urged to prepare reference librarians for the ambiguities and frustrations of working at a reference desk, including constant interruptions, committee overload, and unrealistic time constraints (Walker, 1990). Additionally, peer coaching is recommended as an effective instructional technique (Leven and Frank, 1993).

Catalogers. In addition to emphasizing that catalogers must be instructed on the theories of bibliographic organization (Trainer, 1989) and indexing (Ballard, 1993), writers in the library literature also emphasize the need to instruct catalogers in the following areas: national standards for bibliographic control (Clack, 1993); foreign language skills and the ability to use automated cataloging systems (A.F. Evans, 1993); MARC record formats (Callahan and MacLeod, 1994); and understanding of cataloging from a "nuts and bolts" perspective, as well as the standpoint of analysis, synthesis and evaluation ("Cataloging librarians address staffing needs," 1989). The ALCTS's Committee on Education, Training, and Recruitment for Cataloging identifies the following elements for a training program for entry level catalogers: logistics and organizations of technical services departments and libraries, personnel issues, electronic cataloging, continuing education opportunities, descriptive vocabulary, MARC format, local cataloging practices, access points, subject headings, classification and shelflisting, authority control, online catalog maintenance, and dealing with special formats ("Essential...," 1994). Finally, cataloging practitioners agree that it is important for catalogers to develop a sense of priorities about cataloging, especially in an interdisciplinary world (Curran, 1995) which derives from a complete understanding of the purpose and theory of cataloging (Intner, 1990), and that catalogers should engage in continuing education (Powell, 1988) and preprofessional internships (Riemer, 1993). 
Collection Development Librarians. MLS graduates should possess knowledge of: publishing processes, vendors and jobbers; serials acquisition and control; legal issues (especially copyright); resource sharing; collection evaluation techniques; and preservation techniques. It is also recommended that graduates possess the ability to write a collection development policy (Budd and Bril, 1994); that bibliographers possess subjectspecific knowledge of subjects, authors, and titles (Williams, 1991); and that on-the-job training be used to complement classroom education (Schmidt, 1991).

Science and Technology Librarians. In addition to the competencies that all MLS graduates should achieve, the literature indicates that science and technology librarians must be able to evaluate information for quality, currency, and relevance to a specific problem, and that they must have knowledge of the research habits, work context, and information gathering techniques of scientists and engineers (Stuart and Drake, 1992). It is also emphasized that in order to obtain a working knowledge of the literature of science and technology, MLS students should be taught by faculty who have experience with science and technology (Vazakas and Wallin, 1992). Finally, science and technology librarians must be creative in their assumption of leadership roles in the information profession (Storm, 1994).

Medical and Health Science Librarians. In general, the literature about competencies for medical and health science librarians emphasizes the concept of medical informatics, or the applied use of information science for medical information problems (Ball, Douglas and Lunin, 1988; Detlefson, 1993), as well as the recommendation that health information professionals be employed as faculty to teach potential health information professionals (Creth, 1993). It is further stressed that subjectbased expertise is critical (Ekstrand, Ladner, and Olds, 1990). The Medical Library Association provides guidelines for teaching medical and health science librarians which include the need to instruct students in medical concepts and terminology, the information needs of health professionals, medical cataloging and classification schemes, medical bibliography, and the health care environment (Roper and Mayfield, 1993). Recently, the National Library of Medicine reported that MLS graduates must: be able to apply new information technologies to health care; utilize an interdisciplinary approach to providing health care information; understand the importance of networking; be familiar with and recognize the importance of the Joint Commission on Accreditation of Health Care Organizations' standards for management of information; use media and telecommunications technology to provide remote access to medical data for medical facilities without libraries; develop and utilize quantitative and qualitative measures of the value of information services for health care; and possess knowledge regarding patient education materials, clinical practice guidelines, decision support systems, and computer-based patient records systems (National Institutes of Health, 1995).
Law Librarians. The American Bar Association standards for law librarians require that they possess either a degree in law or in library science; the Association of American Law Schools standards require both degrees in addition to certification through the Association (Bonney, 1991). It is generally agreed that law librarians and directors of law libraries should and do possess legal and library education (Slinger, 1988; Hazleton, 1993).

Corporate Librarians. Corporate librarians must: be able to prioritize information requests, understand the need to deliver information in a timely fashion, recognize the importance of information that is generated within the parent institution, possess a service attitude and a focus on information users as "customers," understand the general principles of business and management (Kendrick, 1990; Tchobanoff and Price, 1993), market library services (Butcher, 1989), and synthesize competitive intelligence information (Dou, 1993). As special librarians, they must also be knowledgeable about specialized document forms such as preprints, patents, and standards (Godert, 1987), must have subject background and business savvy (Cronin, Stiffler, and Day, 1993), and must possess an educational background which effectively integrates business, management, and library theory and practice (James, 1989; Willner, 1993). A survey of Canadian special librarians distills these competencies into three broad areas: information-related and technological skills, management skills, and attitude skills (MacFarlane and Tees, 1993).

Visual Resources Librarians. The literature recommends that library science faculty teaching in this area hold the MA in art history (Robertson, 1991); that MLS graduates enroll in graduate coursework in art (Mahard, 1994), including dual master's degree programs in art and library science (Irvine, 1994); and that MLS graduates complete coursework and continuing education dealing with visual resources, slide librarianship, database creation, image technologies, and automation of art libraries and collections (Jacoby, 1992; Stam, 1993; Boaden, 1994; "Continuing...," 1994; Williamson, 1994). As with other specialties, it is also recommended that students complete internships in art libraries (Blank, 1992; Tucker, 1994). Also emphasized is the need for library science faculty to encourage new audiovisual librarians and archivists to develop standards for treatment of audiovisual resources (Tumer, 1991), and to provide specialized art librarianship courses within the library science curriculum (Robertson, 1994; Todros, 1994).

Music Librarians. Music library practitioners recommend that MLS graduates who wish to work as music librarians have an undergraduate degree in music, that they be able to read music and understand musical styles, and that they possess foreign language skills and a knowledge of music history (Carobine, 1991). It is also suggested that entry level music librarians possess knowledge of music printing and engraving, the structure of music publishing and distribution industries, and cataloging of music materials (Sommer, 1988). Finally, the importance of being able to utilize electronic databases of music scores and sound recordings is stressed (Duggan, 1993). 
Library Systems Analysts / Systems Librarians. Competencies necessary for systems librarians include: the ability to select, install, maintain and analyze integrated systems; advanced knowledge of microcomputers; knowledge of networking and local area networks; knowledge of CD-ROM technology; familiarity with mainframe computers; knowledge of the Internet; the ability to program; understanding of information technology; ability to analyze information systems; and knowledge of automated bibliographic control systems (Boyce and Heim, 1988; Burtle, 1994).

\section{Continuing Education}

The topic of continuing education is very well represented in the library literature about education for librarianship. Continuing education constitutes, in its most formal form, established coursework (both elective and core) within a library school's program; it also comprises informal educational opportunities such as group discussions and sustained professional reading (Washington, 1989; C. Evans, 1990; Boydston, 1992; Latrobe, 1992; Sager, 1993). Other delivery mechanisms for continuing education include mentor programs (Corbin, 1988), satellite programs (Lynch, 1994), in-house lectures ("Free Library...," 1988), journal clubs (Jones, Richmond, Christopher, and Duggar, 1993), library tours (Keally, 1993), participation in and recognition of the importance of professional association activities (Stussey, 1988; Curry, 1992; T.W. Miller, 1992; Richman-Scott, 1993), workshops (Redfield, 1988), and videotaped seminars (Halsted and Goldstein, 1990). Continuing education is particularly heralded in the literature as an effective way to reach individual and specialized populations such as adult learners, small business owners, and ethnic and cultural minorities (Ezell, 1990), and as an effective vehicle for integrating new employees into the structure of large libraries (Grumling and Sheehy, 1993), thus helping to create a sense of common purpose and shared vision (Nelson, 1993).

In addition to topics already identified as necessary for core curricula, writers indicate the following topics as being particularly appropriate for continuing education opportunities: research techniques and publishing venues (Wright, 1993), medical informatics ("NLM grant...," 1992), leadership development (Fineberg, 1993), acquisitions (Thomson, 1994), advanced collection management techniques (Axtmann, 1994), advanced cataloging management techniques (Nevin, 1994), advanced bibliographic instruction techniques (Bumam, 1993), and records management (Nawe, 1991).

Regardless of the type of continuing education being offered, library practitioners indicate that continuing education opportunities must take into account the motivations, qualifications, and leaming or teaching styles of participants (Burgin, 1992) and trainers (Bellardo, 1988; Mulder and Dayton, 1994), and that in order to be effective, continuing education must be accompanied with institutional supports (Havener and Stolt, 1994) and incentives (Segal, 1988).

\section{Conclusions}

Overall, the professional library literature about education of librarians points in the right direction, but avoids direct attention to some of the major issues which today's librarians face. The literature indicates that the world of librarianship is poised on the edge of a technological revolution. This is not totally accurate. The world of librarianship is not poised at the beginning of monumental change, rather it is in the midst of a globally cataclysmic technological, economic, cultural, and information revolution which has successfully obsolesced old "truths." The very heart and soul of librarianship are being catapulted into a new state of being. Consider, for example, traditional cataloging classification schemes and the conspectus approach to collection evaluation and development; these approaches are seriously compromised by the interdisciplinary nature of information in the world of Intemet and hypertext mapping. Or, consider the prevailing characterization of libraries as non-profit institutions. This "truth" is also seriously jeopardized by rapid global economic change which imbues useful information with significant real monetary value.

Even the definition of "the library" has changed. Traditional definitions of "the library," while still valid, are no longer enough. In part, this is because too much of the world's population does not have access to a traditional library. And, traditional libraries cannot provide the diverse and multicultural resources necessary to adequately support the information needs of a world which is no longerdivided into discrete physical, political, social, or cultural units.

The very essence of an information unit is redefined by a geometrically increasing electronic information environment which is characterized by too much, rather than too little input, and which increases the output of information to overwhelming proportions. And, perhaps most cataclysmic is the tangible technological demarcation line which divides the information "haves" and "have-nots" into groups that define a person's lifetime ability to achieve. The world of today's librarian is not a "changing" world; it is a "changed" world. Within this context, library educators must provide new definition to the goals of library education which are reflected in the professional literature.

Inasmuch as the literature of a profession mirrors the current and future realities of its practice, the literature of librarianship seems to indicate a clear direction for library education, even if the reasons cited do not totally take into account the current realities of the information world. Library science educational programs must be visionary, they must include students who do not attend classes at a specific physical facility, and they must be able to change quickly as they embrace new paradigms for the profession. In order to do this, educational programs in library science must:

1) Impel all students to interact with technology, rather than just utilize technology.

2) Integrate the theory and practice of librarianship in ways which stimulate students to engage in critical thinking that culminates not with a mere analysis of current problems, but rather with a vision for the future that they will implement. 
3) Utilize interdisciplinary approaches to problem-solving, innovation, and definition of the profession.

4) Prime students to anticipate change and incorporate it before change "happens" to them.

5) Show students, by example, how to be energetic and enthusiastic as they are challenged to master new concepts and skills on a daily basis.

6) Inspire students to think in ways that are flexible and quick enough to develop and assimilate, in a timely manner, new paradigms which define the profession and its practice.

7) Expose students to diverse cultural experiences which will enlighten and inform their professional decisionmaking.

8) Position "the library" and "information" within defining technological, international, social, economic, political, and cultural contexts.
9) Infuse students with clearly defined professional values and ethics which will help them to prioritize their professional behavior in ways that hold them accountable for their actions and in ways which reflect leadership and confidence.

10) Empower students with an understanding of the basic principles of librarianship which is clear enough to facilitate critical analysis of present practices based on predictions about the future.

The world of librarianship has changed; the education of librarians must also change. In order to survive, librarians can no longer merely tum information into knowledge. The librarians of today must be able to recognize the difference between information and wisdom, and they must be able to evaluate the wisdom of information. This is the challenge for library school educators of the twenty-first century.

\section{BIBLIOGRAPHY}

Abdullahi, I. (1991). "Recruitment and mentoring of minority students." Joumal of Education for Library and Information Science, 33, 307-310.

Abed, F. (1988). "Simulated exercises for media specialist training." Indiana Media Journal, 11(1), 25-27.

Adams, H. R. (1992). "AASL's role in your professional development." Ohio Media Spectrum, 44, 49-51.

Alire, C. (1988, September). "Education for library personnel (special issue)." Colorado Libraries, 14, 8-27.

Anderson, A. J. (1994). "Single white male." Library Journal, 119(2), 56.

Anderson, J. D., Belkin, N. J., Lederman, L. C., \& Saracevic, T. (1988). "Information science at Rutgers: Establishing new interdisciplinary connections." Journal of the American Society for Information Science, 39, 327-330.

Arthur, G. (1992). "Using video for reference staff training and development: A selective bibliography." Reference Services Review, 20(4), 63-68.

Association of College and Research Libraries. Professional Education Committee. (1992). "Education for professional academic librarianship." College \& Research Libraries News, 53, 590-591.
Association of College and Research Libraries. (1989). "Statement on the certification and licensing of academic librarians." College and Research Libraries News, 10, 892-893.

Avram, H. D. (1991). "The future of staff development." In S.S. Intner \& J.S. Hill (Eds.), Cataloging: The Professional Development Cycle (pp.63-66). Westport, CT:Greenwood Press.

Axtmann, M. M. (1994). "Advanced collection management and development institute," March 26-28, 1993: A report. Library Acquisitions: Practice \& Theory, 18, 207-212.

Ball, M.J.; Douglas, J.V. \& Lunin, L.F. (1988). "Informatics and education in the health profession." Journal of the American Society for Information Science, 39(5), 344-347.

Ballard, R.M. (1993). "Indexing and its relevance to technical processing." Cataloging and Classification Quarterly, 16(3), 79-88.

Barron, D. D. (1993a). "A nation at risk, a profession at risk: Will there be school library media specialists in 2003? Part I." School Library Media Activities Monthly, 10(1), 49-50.

(1993b). "Anation at risk, a profession at risk: Will there be school library media specialists in 2003? Part II." School Library Media Activities Monthly, 10 (2), 49-50.

Behrmann, C.A., \& Vogliano, D. (1991). "On training the children's reference librarian." Illinois Libraries, 73, 152-157. 
Bellardo, T. (1988). "Options and trends in the training of information professionals." Journal of the American Society for Information Science, 39, 348-350.

Berry, J. N. (1989). “ALISE in Washington." Library Journal, 114(4), 37-38.

(1993). "The two crises in library education: How and where will we educate librarians?" Library Journal, 118(14), 102.

(1994). "What should we tell Corinne? Does it make any difference which library school?" Library Journal, 119(6), 6.

Blake, V. L. P. (1994). "Faculty productivity, joumal prestige, and school library media faculty." School Library Media Quarterly, 22, 153-158.

Blank, P. P. (1992, Summer). "Ask ARLIS I: On the job training for a career in visual resources and art librarianship." Art Documentation, 11, 69-70.

Boaden, S. (1994). "Education for art librarianship in Australia." Art Libraries Journal, 19 (2), 5-6.

Boyce, B. R. (1994). "The death of library education." American Libraries," 25, 257-259.

and Heim, K.M. (1988). "The education of library systems analysts for the nineties." Journal of Library Administration, 9 (4), 69-76.

Boydston, J. M. K. (1992). "Continuing education and staff development among serials catalogers." Serials Librarian, 22(1/2), 17-38.

Bradley, J. (1993). "Library and information science education at IUPUI." Indiana Libraries, 12(2), 3-7.

Brennen, P. W., \& Sullivan, M. B. G. (1989). "Work/training programs for international health science librarians in American medical school libraries." Bulletin of the Medical Library Association, 77, 170-175.

Budd, J. M., \& Bril, P. L. (1994). "Education for collection management: Results of a survey of educators and practitioners." Library Resources \& Technical Services, 38(4), 343-354.

Burgin, R. (1992). "Public librarians and continuing education: A motivational study." Public Library Quarterly, 12(4), 29-41.

Bumam, P. (1993). "Fine-tuning classroom technique: A peer coaching experience." Research Strategies, 11, 42-46.
Burtle, L. (1994). Meeting the educational needs of systems librarians; A comparative study of schools of information and library science, graduate schools of business, and undergraduate and graduate computer science programs (Thesis, MSLS, University of North Carolina at Chapel Hill).

Butcher, H. (1989). "Business information curricula: An employer's list of essential skills and knowledge." Education for Information, 7, 335-341.

Callahan, D. and MacLeod, J. (1994). "Recruiting and retention revisited: A study of entry level catalogers." Technical Services Quarterly, 11(4), 27-43.

Carobine, T. (1991). "Education and training for music catalogers in the United States." Fontes Artis Musicae, 38, 61-67.

Carpenter, M. (1991). "The education of cataloging librarians." In S. S. Intner \& J. S. Hill (Eds.), Cataloging: The Professional Development Cycle (pp. 97-102). Westport, CT: Greenwood Press.

"Cataloging librarians address staffing needs." (1989). Library Personnel News, 3(3), 40.

Chu, C.M. (1994). "Education for cataloging: A symposium paper." Cataloging \& Classification Quarterly, 16 (3), 2737.

Clack, D. H. (1993). "Education for cataloging: A symposium paper." Cataloging \& Classification Quarterty, 16(3), 27-37.

Clark, A. J. (1992). "Education and training for librarianship and information work: Annual bibliography, 1991." Education for Information, 10, 165-222.

Coffeen, J. D. (1989). "The "before" and "after" of a children's librarian." Indiana Libraries, 8(2), 104-108.

Cole, D. (1993). "Library school: The altemative curriculum." Wilson Library Bulletin, 67(8), 57-59.

Collins, M.E. (1990). “Continuing education for ARL librarians in multi-faceted public service positions." The Reference Librarian, 30, 17-33.

Connell, T. H. (1992). "The need for funded research." OCLC Micro, 8(5), 18-23.

"Continuing education for art librarianship." (1994). Art Libraries Journal, 19(2), 25-29.

Corbin, J.B. (1988). "The education of librarians in an age of information technology." Journal of Library Administration, 9(4), 77-87. 
Cory, K.A. (1994) "The information standard: what it is, how it affects librarianship, and why it has been overlooked." Journal of Education for Library and Information Science, 35, 320-327.

Creth, S. D. (1993). "The health information environment: A view of organizational and professional needs and priorities." Bulletin of the Medical Library Association, 81, 414-420.

Cronin, B., Stiffler, M., \& Day, D. (1993). "The emergent market for information professionals: Educational opportunities and implications." Library Trends, 42, 257-276.

Curran, C.C. (1995). "Perpetuating information overload (librarians are prevented from thinking about information the way their clients do)." American Libraries, 26, 514.

Curras, E. (1993). "The need for theoretical studies in information science." Journal of Information Science, 19 (1), 1.

Curry, E. L. (1992). "The impact of professional associations." Journal of Library Administration, 16(1/2), 45-54.

Dannelly, G. N. (1994). “Continuing education for collection management and development: Professional and survival imperatives." In P. Johnson \& S. S. Intner(Eds.), Recruiting, educating, and training librarians for collection development (pp. 199-211). Westport, CT: Greenwood Press.

Dean's list: "10 school heads debate the future of library education." (1994). Library Journal, 119, 60-64.

DeLuise, A. (1994, Summer). "Lessons from the trenches: Teaching art librarianship and visual resources curatorship." Art Documentation, 13, 84-85.

Detlefsen, E. G. (1993). "Library and information science education for the new medical environment and the age of integrated information." Library Trends, 42, 342-364.

Diaz, J., \& Starkus, K. (1994). "Increasing minority representation in academic libraries: The minority librarian intern program at the Ohio State University." College \& Research Libraries, 55, 41-46.

Dou, H., Hassanaly, P., \& Quoniam, L. (1993). “Technology watch and competitive intelligence: A new challenge in education for information." Education for Information, 11, 35-45.

Duggan, M. K. C. (1993). "Teaching music librarians through very large databases: Local online catalogues, OCLC, and RLIN." Fontes Artis Musicae, 40, 191-197.
Dumond, P.E. (1989). "Library education and employer expectations: The two-year college perspective." Journal of Library Administration, 11(3-4), 59-71.

Duval, B. K., \& Main, L. (1993). "Library education for literacy librarians." Education for Information, 11, 105-121.

Eisenberg, M. B. (1991). "Professional preparation of library media specialists: The state of programs in New York State." The Bookmark, 50(1), 82-85.

Ekstrand, N. L., Ladner, B. H., \& Olds, W. W. (1990). “Cancer information forlibrarians: Medical-subject-based continuing education." Bulletin of the Medical Library Association, 78, 307-311.

Elkin, J. (1992). "The education and training of children's librarians." International Review of Children's Literature and Librarianship, 7(3), 151-154.

"Essential elements of training programs for entry-level professional catalogers." (1994). ALCTS Newsletter, 5 (3), 32-34.

Evans, A. D., \& Tipton, M. H. (1992). "Updating or reforming programs for the preparation of school library/media specialists: A perspective." Ohio Media Spectrum, 44(1), 5-9.

Evans, A. F. (1993). "The education of catalogers: The view of the practitioner/educator." Cataloging \& Classification Quarterly, 16(3), 49-57.

Evans, C. (1993). "Staff development and the school library." Tennessee Librarian, 45(4), 8-12.

Ezell, C. (1990). "A fast track over rocky roads: Continuing education for reference librarians." The Reference Librarian, 30, 59-70.

Fang, J. R., \& Nauta, P. (1991). "IFLA's contributions to education for library and information science." IFLA Journal, 17, 229-231.

Fasick, A. M. (1990). "Carrying on the tradition: Training librarians for children's services." In A. M. Fasick, M. Johnston, \& R. Osler (Eds.), Lands of pleasure: Essays on Lillian $H$. Smith and the development of children's libraries (pp. 19-32). Metuchen, NJ: Scarecrow Press.

Fineberg, G. M. (1993). "Library recruits candidates for minority leadership development: 20 persons to be selected for program." Library of Congress Information Bulletin, 52, 339.

Fisher, W., \& Matarazzo, J. (1993). "Professional development for special librarians: Formal education and continuing education for excellence." Library Trends, 42, 290-303. 
Foderingham-Brown, M. (1993). "Education for multicultural librarianship: The state of the art and recommendations for the future. In K. Parrish \& B. Katz (Eds.)," Multicultural Acquisitions (pp. 131-148). Binghamton, NY: Haworth Press.

"Free Library of Philadelphia fosters staff development." (1988). Library Journal, 113(3), 116.

Freiband, S. J. (1992). "Multicultural issues and concerns in library education." Journal of Education for Library and Information Science, 33, 287-294.

Garrison, G. (1988). "Challenges to information science education." Journal of the American Society for Information Science, 39, 362-366.

Gash, S., \& Reardon, D. F. (1988). "Personal transferable skills for the modem information professional: A discussion paper." Journal of Information Science, 14, 285-292.

George, M. W. (1994). "Monitor as mentor: Intemet's role in professional growth." College \& Research Libraries News, $55,142-143$.

Godert, W. (1987). "Educating the public librarian, educating the special librarian--Is there a common future?" Education for Information, 5, 187-197.

Gorman, M. (1992). "How cataloging and classification should be taught." American Libraries, 23, 694-697.

"Graduates eam MLS via Mind Extension television network." (1994). Wilson Library Bulletin, 68(8), 18.

Greene, E., \& Cullinan, B. E. (1988). "Educating librarians to serve early childhood." School Library Journal, 34(11), 54.

Grey, E. B. (1991). State certification requirements in the United States, 1987-1988 and educational preparation for the practice of public librarianship. (Thesis, MSLS, University of North Carolina at Chapel Hill).

Grumling, D. K., \& Sheehy, C. A. (1993). "Professional development program: Training for success within academic librarianship." College \& Research Libraries, 54, 17-24.

Halsted, D. D., \& Goldstein, C. H. (1990). "Continuing education through videotapes." Bulletin of the Medical Library Association, 78, 194-195.

Hannigan, J.A. (1994). "A feminist standpoint for library and information science education." Journal of Education for Library and Information Science, 35, 297-319.
Hansel, P. (1991). "What NCCU has meant for the education of librarians.” In B. F. Speller (Ed.), Educating black librarians (pp. 141-142). Jefferson, NC: McFarland \& Co.

Havener, W. M., \& Stolt, W. A. (1994). "The professional development activities of academic librarians: Does institutional support make a difference?" College \& Research Libraries, 55, 25-36.

Hayes, R. M. (1988). "Education of the information professional: A library school perspective." Journal of the American Society for Information Science, 39, 312-317.

Hazelton, P. A. (1993). "Law libraries as special libraries: An educational model." Library Trends, 42, 319-341.

Hempstead, J. (1988). "Educational requirements update for school library media personnel. "Colorado Libraries, 14, 23-24.

Heyser, T., \& Heyser, R. G. (1989). "The role of library education in meeting the personnel needs of public and school libraries." Journal of Library Administration, 10(4), 3-19.

Holmberg, Borje. (1991). "Open and distance leaming in continuing education." IFLA Journal, 17, 274-282.

Hurd, J. M. (1988). "Technology: An agent for change in education for information." Journal of the Society for Information Science, 39, 323-326.

Immroth, B. F. (1991). "Education of children's and youth librarians: Competencies developed by ALSC." In US-USSR colloquium on library services to children (pp. 44-55). Chicago: American Library Association.

Intner, S. S. (1990). "Cataloging practice and theory: What to teach and why." Journal of Education for Library and Information Science, 30, 333-336.

(1991). "Education for the dual role responsibilities of an access services librarian." The Reference Librarian, 34, 107-126.

Irvine, B. J. (1994). "Dual master's degree in art librarianship, Indiana University, USA.” Art Libraries Journal, 19(2), 9-11.

Jacoby, T. B. (1992). "Emerging technologies and education for visual resources professionals." Art Documentation, $11,125-126$.

James, S. (1989). "Understanding managerial principles and practices: Management training for business information professionals." Education for Information, 7, 355-363. 
Johnson, I. M. (1991). "Teaching online information systems: Perspectives on the British system." IFLA Journal, 17, 241-247.

Jones, C. J. (1993). "Charting a path for health sciences librarians in an integrated information environment." Bulletin of the Medical Library Association, 81, 421-424.

Jones, D. A., Richmond, C. E., \& Christopher, K. A. (1993). "The journal club as an educational modality for librarians: The Louisiana State University Medical Center in Shreveport experience." LLA Bulletin, 55, 192-196.

Jones, W. G. (1991). "The education of academic librarians: How many degrees are enough?" College \& Research Libraries News, 52, 584-586.

Jordan, C. L. (1991). "With twenty-five carefully selected students: An informal account of black library education." The Georgia Librarian, 28, 61-62.

Jul, E. (1990). "Looking at library and information science education.” PNLA Quarterly, 54, 23-24.

Kaatrude, P.B. (1992). "Librarian certification and licensing: A Brief accounting." Public Libraries, 31, 155-157.

Kaula, P.N. (1988). "Hundred years of library and information science education: Evaluation and trend." Herald of Library Science, 27, 170-177.

Keally, J. (1993). "Staff development at the University of Tennessee Knoxville Libraries.” Tennessee Librarian, 45(4), 14-18.

Kendrick, A. (1990). "The educational background and work experience of academic business librarians." $R Q, 29,394-399$.

Kendrick, C. L., Lipkind, J., \& Clinkscales, J. (1990). "Minority internship/scholarship in library and information science (at SUNYStony Brook)." College \& Research Libraries News, 51,965 .

Kibirige, H.M. (1993). "Theoretical foundations of development information science."International Information and Library Review, 25, 1-14.

Koenig, M. E. D. (1993). "Educational requirements for a libraryoriented career in information management." Library Trends, 42, 277-289.

Latrobe, K. H. (1992). "Continuing education needs and the professional reading of school library media specialists." Journal of Youth Services in Libraries, 5, 407-410.
Lenox, M. F. (1993a). "Developing and enhancing multiethnic understanding." Journal of Education for Library and Information Science, 34, 246-250.

(1993b). "Educating the black librarian and information professional for leadership in the twenty-first century." In S. F. Biddle (Ed.), Culture keepers: Enlightening and empowering our communities (pp. 192-195). Newark, NJ: The Black Caucus of the American Library Association.

Lester, J. (1993). "Education in response to change." Journal of Library Administration, 18(3/4), 39-54.

(1994). "Competency colloquium: Developing the competency statement." Public Libraries, 33, 81-91.

(1990). "Education for librarianship: A report card; one educator examines what course is best to solve the crises confronting our schools." American Libraries, 21, 580-586.

Levene, L., \& Frank, P. P. (1993). "Peer coaching: Professional growth and development for instruction librarians." Reference Services Review, 21(3), 35-42.

Lewis, C. G. (1993). "Developing personnel." In B. B. Carson \& J. B. Smith (Eds.), Renewal at the schoolhouse (pp. 4960). Englewood, CO: Libraries Unlimited.

Lindberg, C.H. (1990). "Certification, status, and salaries." Journal of Education for Library and Information Science, 31, 157-161.

Louw, A. (1994). "The evaluation of the performance of students during professional education and in practice." Mousaion, 12(1), 34-45.

Lowry, C. B. (1990). "An interview with Edward Holley." Library Administration \& Management, 4, 118-122.

Lynch, T. P. (1994). "How Nebraska has responded with telecommunications and long-distance education." Rural Libraries, 14(1), 3-10.

MacFarlane, J. and Tees, M. (1993). "Special library education and continuing education in Canada." Library Trends, 42(2), 304-318.

Mahard, M. (1994). "Educating visual resources professionals." Art Documentation, 13, 75-76.

Main, L. (1990). "Research versus practice: A "no" contest." Journal of Education for Library and Information Science, 30, 226-228. 
Makinen, Rita. (1991). "Continuing professional education on the management of change in academic and research libraries." IFLA Journal, 17, 289-294.

Mandernack, S.B. (1990) "An assessment of education and training needs for bibliographic instruction librarians." Journal of Education for Library and Information Science, 30, 193-205.

Martin, S. (1994). "Librarianship and certification." College and Research Libraries News, 9, 567.

Massey-Burzio, V. (1991). "Education and experience; Or, the MLS is not enough." Reference Services Review, 19(1), 72-74.

Mayfield, M. K. (1993). "Beyond the classroom: Self-direction in professional leaming." Bulletin of the Medical Library Association, 81, 425-432.

McCook, K. (1993a). "Hispanic librarians debate issues at first Latino summit.” Library Journal, 118(15), 14-15.

(1993b). "Project Century 21 embodies decade themes." Library Personnel News, 7(3), 1-3.

\& Gonsalves, T. O. (1993). "The research university and education for librarianship: Considerations for user-centered professionals in libraries." Journal of Liórary Administration, 19(3/4), 193-207.

McMurry, N. (1988). "From library student to library professional: Smoothing the transition for the new librarian." North Carolina Libraries, 46, 209-213.

Meiseles, L., \& Feller, S. (1994). "Training serials specialists: Internships as an option." Library Administration \& Management, 8, 83-86.

Miller, M. L. (1990). "Fill in the data blank." School Library Journal, 36(2), 41.

(1991). "Empowering people through libraries: The role of the profession." North Carolina Libraries, 49, 198-201.

Miller, T. W. (1992). "AECT's role in professional development." Ohio Media Spectrum, 44, 52-54.

Moll, J. K., \& Flood, B. J. (1988). "Information science and information-related education programs: Theirdiversity and accreditation." Journal of the American Society for Information Science, 39, 318-321.
Mulder, C., \& Layton, B. (1994). "Defining what instructional librarians need to know about information technologies." Medical Reference Services Quarterly, 13(1), 111-117.

National Institutes of Health. "National Library of Medicine. Long Range Plan." (1995). Re port of the planning panel on the education and training of health sciences librarians. Bethesda, Maryland: National Institutes of Health.

Nawe, J. "Need and priority areas." IFLA Journal, 17(3), 310314.

Nelson, S. S. (1993). "Continuing education for public library employees: Tennessee provides quality and quantity." Tennessee Librarian, 45(4), 19-25.

Nevin, S. (1994). "Minnesota Opportunities for Technical Services Excellence (MOTSE): An innovative CE program for technical services staff." Library Resources \& Technical Services, 38, 195-198.

Nicholson, F. and Bridgeland, A. (1991). "Continuing education: An Australian perspective.”IFLA Journal, 17(3), 295-302.

"NLM grant to universities." (1992). Library Journal, 117(16), 30.

Oen, C. and Cooper, M. (1988). "Professional identify and the information professional." Journal of the American Society for Information Science, 39(5), 355-357.

Office for Accreditation. (1992). Standards for accreditation of master's programs in library and information studies. Chicago: American Library Association.

Ostler, L.J. \& Therrin, C. (1995). "Library education: Setting or rising sun?" American Libraries, 26, 683-684.

Otero-Boisvert, M. (1993). "The role of the collection development librarian in the 90 s and beyond." Journal of Library Administration, 18(3/4), 159-170.

Pemberton, J. M., \& Prentice, A. (Eds.). (1990). Information science: The interdisciplinary context. New York: NealSchuman.

Penniman, W.D. (1991). "Focusing on core competencies." The Journal of Academic Librarianship, 17, 211-212.

Perritt, P. H. (1994). "School library media certification requirements: 1994 update.” School Library Journal, 40(6), 32-51. 
Petrowski, M. J., \& Wilson, L. A. (1991). "Avoiding horror in the classroom: In-house training for bibliographic instruction (teaching reference librarians to be effective BI instructors)." Illinois Libraries, 73, 180-186.

Powell, R. R. (1988). "Sources of professional knowledge for academic librarians." College \& Research Libraries, 49, 332-340.

Preschel, B. M. (1988). "Education of the information professional: What employers want." Journal of the American Society for Information Science, 39, 358-361.

Redfield, G. (1988). "Workshop alert: How to be prepared to give an effective workshop." Colorado Libraries, 14, 15-16.

Richman-Scott, E., \& Beach, M. (1993). "Joining forces: Developing excellence through diversity." New Jersey Libraries, 26(4), 19-22.

Riechel, R. (1989). Personnel needs and changing reference service. Hamden, CT: Library Professional Publications.

Riemer, J. J. (1993). "A practitioner's view of the education of catalogers." Cataloging \& Classification Quarterly, 16(3), 39-48.

Robbins, J.B. (1990). "Yes, Virginia, you can require an accredited master's degree for that job!" Library Journal, 115, 40-44.

Robertson, J. (1991, Fall). "Survey of library schools in North America: Educational and training opportunities for careers in art libraries and visual resources collections." Art Documentation, 10, 141-143.

(1994). "Education and continuing training for art librarianship: A North American perspective." Art Libraries Journal, 19(2), 12-16.

Rogers, S. L. (1994). "Accredited library school education in ethics." Journal of Education for Library and Information Science, 35, 51-55.

Roper, F. W. (1991). "Distance education in library and information science education." IFLA Journal, 17, 283-288.

— \& Mayfield, M. K. (1993). "Surveying knowledge and skills in the health sciences: Results and implications." Bulletin of the Medical Library Association, 81, 396-407.

Sabzwari, G. A. (1993). "Closing of library schools in United States." Pakistan Library Bulletin, 24, i-viii.

Sager, D. J. (1993). "Keeping current in the profession." Public Libraries, 32, 309-313.
Schmidt, K.A. (1991). "The education of the acquisitions librarian: A survey of ARL acquisitions librarians." Library Resources and Technical Services, 35, 7-22.

Schneider, K. G. (1994). "Train for the mission: Librarians vs. top guns." Wilson Library Bulletin, 68(), 21-22.

Segal, B. (1988, September). "Aurora Public Library career development plan." Colorado Libraries, 14, 9.

Settel, B., \& Marchand, D. A. (1988). "Syracuse University School of Information Studies: A tradition of innovation." Journal of the American Society for Information Science, 39, 331-333.

Sharma, R. N. (1993). "American and South Asian library educators discuss library and information science education." Journal of Education for Library and Information Science, 34, 86.

Shonrock, D. D., \& Mulder, C. (1993). "Instruction librarians: Acquiring the proficiencies critical to their work." College \& Research Libraries, 54, 137-149.

Sineath, T. W. (1992). "Information science in the curriculum." Journal of Library Administration, 16(1/2), 55-65.

Slinger, M. J. (1988). "The career paths and education of current academic law library directors." Law Library Journal, 80, 217-239.

Sommer, S. T. (1988). "Teaching collection development in context." Fontes Artis Musicae, 35, 195-197.

Speller, B. F. (Ed.). (1991). Educating black librarians. Jefferson, NC: McFarland \& Co.

Stam, D. C. (1992). "What reference librarians need to know." The Bookmark, 50(2), 173-179.

- (1993). "What do art information professionals want to learn about information technology and how do they want to learn it?" Art Documentation, 12, 3-5.

Storm, P. (Spring 1994). "Issues related to the education and recruitment of science/technology librarians." Science \& Technology Libraries, 14, 35-42.

Stuart, C., \& Drake, M. A. (1992). "Education and recruitment of science and engineering librarians." Science \& Technology Libraries, 12(4), 79-89.

Stussey, S.A. (1988). "The MLS: A necessary credential for the professional librarian."Catholic Library World, 60, 126-129. 
Tallman, J. I. (1991). "Each one an individual: Needs and satisfaction levels of international students in United States Library and Information Science programs." IFLA Journal, 17, 235-240.

Tassia, M. R. (1990). "Alternatives in the education of school library media specialists.”'In S. S. Intner \& K. E. Vandergrift (Eds.), Library Education and Leadership (pp. 209-217). Metuchen, NJ: Scarecrow Press.

Tchobanoff, J. B., \& Price, J. A. (1993). "Industrial information service managers: Expectations of, and support of, the educational process." Library Trends, 42, 249-256.

Tees, M. H. (1991). "Harmonization of education and training for information professionals." IFLA Journal, 17, 232-234.

Todros, R. (1994). "Training for art librarianship in Italy." Art Libraries Journal, 19(2), 17-18.

Trainer, K. A. (1989). "Dollars and sense: Training catalogers." In S. S. Intner \& J. S. Hill (Eds.), Recruiting, educating, and training cataloging librarians (pp. 367-374). New York: Greenwood Press.

Tucker, L. (1994). "Education for art librarianship in the United Kingdom.” Art Libraries Journal, 19(2), 19-21.

Tumer, J. (1991). "Training for audiovisual archivists and librarians." IFLA Journal, 17(3), 248-255.

Varlejs, J. (1993/1994). "Educating library/information professionals to serve a diverse society." New Jersey Libraries, 27(1), 13-15.

Vazakas, S. M., \& Wallin, C. C. (1992). "Where are all the science librarians?” College \& Research Libraries News, 53, 166-167.

Walker, L. (1990). "All I really needed toknow I didn't leam in library school." North Carolina Libraries, 48, 258-259.

Washington, N. (1989). "Focus on the academic librarian: Job satisfaction and continuing education needs." The Southeastern Librarian, 39, 103-105.
Wedgeworth, R. (1991). "A quiet revolution and the fragility of graduate library education.” The Bookmark, 49(4), 262-263.

Weingand, D.E. (1994). "Competence and the new paradigm: Continuing education of the reference staff." The Reference Librarian, 43, 173-182.

(1991). "The continuum of library education: Maintaining competence through the professional worklife." IFLA Journal, 17, 266-273.

White, H.S. (1991). "Bibliographic instruction and the library school curriculum." Journal of Education for Library and Information Science, 32, 194-202.

(May 15, 1995). "Educating for the now and future profession." Library Journal, 120, 44-46.

Williams, L.B. (1991). "Subject knowledge for subject specialists: What the novice bibliographer needs to know." Collection Management, 14(3-4), 31-47.

Williamson, M.F. "Education for art and culture librarianship in Canada." Art Libraries Journal, 19(2), 22-24.

Willner, R. A. (1993). "Education for library and information management careers in business and financial services." Library Trends, 42, 232-248.

Wright, P. (1993). "A teacup idea: The research retreat." College \& Research Libraries News, 54, 83-85.

Rashelle S. Karp is Professor of Library Science, Department of Library Science, Clarion University of Pennsylvania.

Tonya Allen is a recent graduate of the accredited MSLS program offered by the Department of Library Science, Clarion University of Pennsylvania. 